\title{
Discursive Strategies and Media Representation of Conflicts
}

\author{
Naeem Afzal ${ }^{1}$ \\ ${ }^{1}$ Department of English, College of Sciences \& Humanities, Prince Sattam bin Abdulaziz University, Saudi \\ Arabia \\ Correspondence: Naeem Afzal, Department of English, College of Sciences \& Humanities, Prince Sattam bin \\ Abdulaziz University, Saudi Arabia. E-mail: naeemafzalawan@gmail.com or n.awan@psau.edu.sa
}

Received: November 2, 2018 Accepted: November 29, 2018 Online Published: January 29, 2019

doi:10.5539/ijel.v9n2p1 URL: https://doi.org/10.5539/ijel.v9n2p1

\begin{abstract}
The media's tendency to widely represent conflicts, through legitimization or de- legitimization, makes us believe that media narratives may not be perceived as 'neutral stances' for the public consumption. This study investigates the policy of a mainstream newspaper, The News International (NI), in Pakistan and discursive strategies manipulated by its editorial writers to portray the Arab Spring. It, specifically, examines how the selected newspaper editorials thematically constructed the uprising; (re) formulated the public opinion by echoing the Arab Spring-centred perspectives; and mostly backed the revolting protesters against the dictatorial rules in Tunisia, Yemen, Egypt, Libya and Syria. The data consist of purposefully selected editorials, which were published between January 2011 and December 2012. This particular timeframe has been distinguished for peak media coverage of the events. The qualitative data (editorial content) are analysed by using NVivo. Through discourse analysis approach, it is revealed that editorial writers employed several recurrent themes (e.g., protests, democracy, horror) to project a positive image of the protesters' movement and fully utilised their prerogative in constructing a 'pro-Arab Spring' discourse. This study concludes that such 'opinion discourses' serve as an eye-opener to the role of media in representing conflicts from different angles while staying in different societies. It also provides insights into the ways newspapers (dis) empower readers by promoting certain factions of a conflict and devaluing others.
\end{abstract}

Keywords: media representations, discourse analysis, discursive strategies, newspaper editorials

\section{Introduction}

In today's world of contemporary media, reality is controlled by media narratives. Day-to-day events are produced which carry certain ideological implications and play ideological roles of producing "empowered readers". Thus, media products in making decisions and choices discursively position readers. By constructing such powerful narratives of who 'we' are, the media are involved in the practice of separating 'us' from 'them' or 'others' who do not understand or share what 'we' believe as true (Fulton, 2005a). Similarly, social realties in the media accounts, for instance a conflict, are also constructed under the influence of specific groups or parties to promote their own agenda (Hussain \& Munawar, 2017). The media "version" of reality which influences the public knowledge and beliefs, originates in the interests of those who produce it (Fairclough, 1995). The media are intricately involved in the relation of power and ideology (Johnson \& Milani, 2010). The hidden power of media discourse, which is reflected in activities such as news reporting and tendencies adopted to produce events, has cumulative effects and operates through specific ways of handling causality, agency and placing readers (Fairclough, 2013). It is invariably persuasive and widely circulated as it (re) shapes public opinion (Talbot, 2007). The power of the press to persuade audience becomes more effective if its coverage interest readers consistently. The news media, as most successful and effective actors, manufacture public consent through the policies of legitimating certain elite groups such as the politicians (van Dijk, 1985). Newspapers construct news based on the world events that need to be noticed. For instance, some debatable events are put on the public agenda, while others are omitted, in order to draw the readers' attention towards such events and highlight their significance publically (Fulton, 2005b).

Newspaper content reflects thinking of corridors of power and serves as a rhetorical document with embedded ideologies (Ng, 2008) or tinted by official ideology of their writers (Fowler, 2013). For instance, editorial writings as subjective opinion pieces (Lee \& Lin, 2006) or opinion discourse (van Dijk, 1998b) demonstrate strong tendency of media one-sidedness (Fowler, 2013) and express power and dominance (van Dijk, 1992). The 
editorials as newspaper representatives promote certain beliefs which align with the implied news media ideologies manifesting (de) legitimized means espoused to accomplish certain objectives (Fairclough, 2013). We experience the media as consumers of various forms of media outputs or productions. This means what we consume is actually the meaning of the media outputs, for instance, in newspaper stories. This meaning severs as the base of informational aspects of media forms, thrills and pleasures. Media studies make sense of media outputs, critically examine the media forms and meanings and stress the point that the media and their outputs are not just natural, obvious or even based on any censuses while portraying the world to us (Long, 2014). In media representation of issues, themes disseminate writers' representations of events, individuals and groups based on the information selected through wide ranges of rhetorical options, for instance, comparison and contract, problems, solutions and so on (Wenden, 2005). The practice of analysing themes empowers researcher to capture global aspects of news media discourse as a whole since the techniques works at a global level of discourse rather than treating isolated words or sentences alone at a micro-level. Hence, presence of themes in fact signals global nature of discourse (van Dijk, 2013).

This article represents how the NI framed the Arab Spring as one of the mainstream newspapers in Pakistan which covers conflicts and affairs of international standing (Shabir, Khan, Adnan, \& Safdar, 2014). The newspaper is assumed to represent a non-Arab media perspective on the conflicts. The purpose has been to explore how the Arab uprising was framed outside the Arab world-supposedly presenting a more realistic assessment of the events given that the newspaper had no direct associations with the two sides of the conflict: the Arab Spring protesters and the authorities (ruling elite).

\subsection{Problem Statement}

The media, being in the hands of the powerful, play a pivotal role in transforming, taming and escalating conflicts, spread the image of the 'others', bring diverse perspectives on conflictual issues and suggest ways to address these issues - their content filled with a variety of themes (Junne, 2013). The pervasive nature of the mass media in this contemporary world have been acknowledged as ever stronger than before with their discursive strategies tending to be more propagandist than journalistic (Zahid, 2016). The media discourse, which reproduces conflicts, is worth exploring from several dimensions of which the ideological one has serious implications. The media (re) shape public mind-set within a particular society and their discourse (dis) empower readers to either favour one side or oppose the other in a two-sided conflict. Given the case of the Arab Spring, this study makes sense of the media perspective of a non-Arab mainstream newspaper (NI) originated in Pakistan in an attempt to draw a picture of the Arab Spring event as a view from abroad. It qualitatively examines how the senior media workers, newspaper editors, informed readers through their editorial columns and how they influenced the readers' decision making power to interpret the events or (dis) favour the actors: authorities or protesters. It employs discourse analysis framework and examine various themes used by the editorial writers as a discursive strategy to (de) legitimise certain aspects/actors while constructing the uprising in Tunisia, Yemen, Egypt, Libya and Syria. It contributes to pointing out the discursive roles in representing contemporary events, involving chaotic situations and violent incidents sparked due to denial of publically claimed social injustice and inequality, and in disseminating knowledge and information. The social media relatively received more attention by researchers in examining the Arab Spring portrayals. Contrastingly, little attention has been paid to the contribution of the news media in spreading the revolution (Lindsey, 2013). The existing research literature demonstrates how some of the news media outlets kept the masses abreast of the Arab Spring based on their political or national orientations. Further, it is worth exploring how the Arab Spring was portrayed in the media outside the countries of the uprising 'supposedly' a more neutral stance on the events, for instance the case of Pakistan, provided that some of the state owned-media in the countries of the uprising mostly represented no violence (Ramadan, 2014).

\subsection{Research Objectives}

This study relies on the following research objectives:

- To investigate the Arab Spring representation by the NI editorial writers.

- To examine discursive strategies used by the editorial writers.

- To probe 'for' or 'against' stance towards the uprising. 


\subsection{Research Questions}

This study answers the following research questions:

- How do the NI editorial writers represent the Arab Spring?

- What discursive strategies do the editorial writers employ to portray the uprising?

- What is the NI's perspective on the conflict, for or against?

\section{The Arab Spring: A Contagious Break Out}

The term 'Arab Spring' symbolises nationwide protests which flared up in the Middle Eastern and North African Region, in the late months of 2010 and the early months of 2011, to forcibly bring 'change' against dictatorial regimes (Blaydes \& Lo, 2012). The wave of anti-regimes protests overthrew age-old regimes in Tunisia, Yemen, Egypt and Libya with the exception of Syria where the protesters had to encounter substantial fatalities and the regime has survived since then (Aday, Farrell, Lynch, Sides, \& Freelon, 2012). The Arab Spring protests first sparked in Tunisia followed by the death of 26-year-old Mohammad Bouazizi who was a primary breadwinner for his family. He despondently committed suicide after facing harassments from municipal authorities which seized his weighing scales and cart. Following the incident, Tunisians launched protests against human rights violations, police brutalities and lack of accountability (Karkouti, 2016).Consequently, Tunisian President Bin Ali stepped down in early 2011 (Acemoglu, Hassan, \& Tahoun, 2014). After Tunisia, the protests broke out in Yemen and ended in the removal of 33-year-old rule of President Saleh. Protesters demanded an end to economic instabilities, political turmoil, corruption and social abuses (Moaddel, 2012). The anti-regime protests in Tunisia also influenced Egyptians who protested against social inequalities and human rights violations and demanded more freedom and democratic establishment (Kashefi, 2013). Resultantly in 2011, President Mubarak had to step down and quit power in the face of anti-regime demonstrations. On February 17, 2011, Libyans started protesting against decade-old regime of Qaddafi in Libya and expressed dissatisfaction over deeply rooted system of patronage, unemployment and corruption. Later, the country was indulged into civil war because of conflicts between military, protesters and Qaddafi's loyalists (Abushouk, 2014). Ultimately, Qaddafi was apprehended by rebel-protesters and killed in October 2011 (Laub, 2011). The Arab Spring demonstrations broke out in Syria in 2011, which demanded release of schoolchildren detained for anti-regime slogans (Moaddel, 2012) and removal of 48-year-old emergency rule. President Assad was blamed for creating colonialism like situations and bombing his own countrymen (Hashemi, 2013). The Arab Spring in Libya and Syria we reported worse than other countries due to killings of protesting citizens (Khosrokhavar, 2016).

\section{Theoretical Approach}

Discourse analysis is a domain, which thoroughly examines the texts in their social, political and cultural contexts (van Dijk, 1995). Discourse is naturally ideological which involves values and beliefs representing relations between people and groups, distributes "social powers" and "social goods" and helps identifying insiders and outsiders (Gee, 2014). It conveys beliefs, thoughts and feelings, urges people to adopt a particular line of thinking (van Dijk, 1997) and requires the existence of social institutions where group members can raise their voice as writers (van Dijk, 1998a). It has been further suggested that discourse endorses power with ideological influences (Fairclough \& Wodak, 1997). In addition, discourse exhibits powers by influencing worldviews and actions, constituting social reality and prompting resistance or compliance. It generates power to spread ideological differences and stimulate public support (Zahid, 2016). Analysis of discourse provides insights into social problems (van Dijk, 1985) and is meaningful for analysing varied forms of interactions in different contexts including media messages (Fairclough, 2013). Discourse analysis also helps examine the association between media messages and their sociocultural contexts (van Dijk, 2004), the content of the language, themes or issues discussed in a newspaper article (Gee, 2014).

Discourse analysis also reveals complexly reconceptualised relationship between the notions of ideology, discourse and text (Canagarajah, 1999). The approach is also suitable to consider the ways language is employed to represent different understandings and worldviews (Partridge, 2012). The application of discourse analysis to newspaper editorials in particular offers meaningful insights and understanding of media perspectives (Gnanaseelan, 2012). Discourse analysts also focus on how the meanings appear in different texts while some others critically examine issues related to power, ideology and inequalities. Representation in discourse analysis means the language employed in a text which assigns meanings to groups, social practices adopted by them and the events. Modes of representations in discourse analysis diverge relying on the nature of perspectives to be constructed (Wenden, 2005). Discourse analysis oversteps the boundaries of content analysis as it systematically accounts for various structures of news reports (van Dijk, 1991.) Discourse analysis is meaningful approach to 
explore a diversity of media texts (e.g., see De Wet, 2001, Gnanaseelan, 2012, Gnanaseelan, 2015; Ciechanowski, 2012).

In discursive analysis, themes are traced to provide a critical analysis of the chosen literature (Paltridge, 2012). Themes indicate patterns across data sets and play an important role in rigorously describing a particular phenomenon. The dissection of various portrayals or narratives into themes leads to unfolding more information about the vocabulary used for descriptions (Cassol, Pétré, Degrange, Martial, Charland-Verville, Lallier et al., 2018). Discursive themes in relation to the macro-context of institutions and ideologies represent the role of politics in media representation of violence (De Wet, 2001). Themes in the press exemplify global meanings of news reports and uncover media constructions of polarised or dichotomous discourse and in-group (us) and out-group (them) relations (van Dijk, 1991). Themes also provide glimpse of media outlets (newspapers) covering various events (Petrella, 2014). Mikkola (2017) also observed that themes combine issues and topics that journalists decide to share with the public and are utilised for maintaining the strategies of discursive (de) legitimation. Themes have greatly contributed to the portrayals of international conflicts of varying discursive nature and media (de) legitimisations (e.g., see Törnberg \& Törnberg, 2016; Ledwell, 2104; Krotofil, 2018). Under the influence of such theoretical background, this article investigates how the Pakistani newspaper (NI) through the journalistic strategy of employing themes framed the Arab Spring conflict. The purpose is to examine the events as narrated by non-Arab editors which generally received less attention particularly in the context of Pakistan.

\section{Literature Review}

Probing the contribution of the news media in covering the Arab Spring is a valuable academic pursuit (Abusharif, 2014). Media impact on the public can better be realised by understanding the way the media content is produced (Shoemaker and Reese, 2013). One of the previous studies claimed that Al Jazeera news stories, concerning the role of social media in spreading information and its impact on uprising in Egypt, positively framed the contribution of communication technologies as agents for spreading social and political change around the Arab world, facilitating protests and indicating arrival of an Internet revolution (Campbell, 2012). Media as a powerful tool of war is used in institutions which adopt selective democracy relying on personal gains. Since the symbolic self-immolation of Mohammed Bouazizi in December 2010 in Tunisia, the Middle East plunged into unprecedented turmoil and the people vigorously protested against dictatorial administrations as reported by the international media. Surprisingly, some independent media outlets in the uprising countries that tried to propagate anti-regime demonstrations were forcibly shut down. Instead, the state-owned media in these countries reported mostly empty streets and denied any signs of revolutions (Ramadan, 2014). Based on their political orientation, newspapers around the globe have demonstrated the media tendency of 'under-reporting' or 'over-reporting' events as seen in the media coverage of the Arab Spring in Libya. Hence, arguably, it was perceived that more pressure was exercised on the media in non-democratic governments than democratic governments (Baum \& Zhukov, 2015).

The Arab Spring received worldwide attention of academia, policy makers and the news media. The protest literature strongly indicates that elements posing threat to any type of status quo are negatively portrayed in the media. The study about stories from news organisations belonging to the United States (NY Times, Newsweek, USA Today, The Foreign Affairs) and the Middle East (Al-Jazeera, The Gulf News) which covered the uprising in Egypt, Syria, Libya, Tunisia, Bahrain, Yemen and Jordon revealed that media coverage of the protests was determined by the level of deviance in goals and tactics adopted by the Arab Spring protest groups-more deviance on the part of the protesters indicated more negative media portrayals (Rasul \& Asim, 2014). Some other contextually varied subjective media portrayals, for instance, the editorials as mouth pieces of a newspaper largely neglected even some violent actions of the protesters and almost positively envisioned the Arab Spring as a future movement of 'change' and by large opposed the authoritative rules in the countries of the uprising. The previous research on editorials published by the non-Arab newspaper The News International (Pakistan) and the Arab newspaper Arab News (Saudi Arabia) claimed that both the newspapers treated the protesters as 'us' through positive self-representations and the authorities as 'them' through negative other-representations (Afzal, 2017).

The media representation of the Arab Spring has revealed that news coverage may not directly influence the policy rather it provides environment in which a policy is created. Global news media has become a source of quick real-time information for policy makers, increased diplomatic communication and directed the world attention to issues like the Arab Spring. The international news coverage simply forces policy makers to respond to events like the uprising which received attention in all media communities (Dube, 2013). The Arab Spring narrative also produced controversies among intelligentsia from different fields, analysts, researchers 
commentators around the globe in relation to its causes and reasons including the name (Arab Spring) given to the movement. Explored from critical discourse analytic perspectives, some of the English and the Arabic (Western, Arab, Islamic countries) mainstream news media discursive constructions divided into news, editorials and opinion texts identified the main actors and various news values. The study concluded that the Arab Spring events and actors were positively and negatively represented. The lexical choices and representation strategies indicated politically, socially and ideologically polarized news stories of the Arab Spring and existence of contrasting themes such as democracy vs. dictatorship, peace vs. violence, government vs. regime and so on (Alian, 2016).

The Arab Spring revolutions generated a new set of images for scholars to investigate and enriched the discourse on the Arab world. The coverage of revolts by discourses and images in the US media suggested that socio-political changes in the Arab world forced a revision of corporate media paradigm in a typical manner. One of the most important developments has been the favourable treatment of Arabs by the media but a sea-change representation of Arabs in the US was not claimed as the media continued to promote their right wing polices (Salaita, 2012). The coverage of the Arab Spring unrest in Tunisia, Algeria, Yemen, Egypt, Libya, and Syria by five transitional Arab news channels Al Jazeera, Al Jazeera English, Al Arabiya, Alhurra and BBC Arabic revealed similarities in the media practice of applying human interest and political frames (Bruce, 2014). The media also framed the Arab Spring by using military vocabulary due to involvement of the Egyptian military in the conflict - representing civil demonstrations as a military battle. Hence, the language was utilised in the media discourse to signify the news, participants, actors and actions of different parties (Youssef, Arafa, \& Kumar, 2014).

The media coverage of the Arab Spring through diverse sourcing practices suggested a more global outlook in international coverage of the events - than domesticated - and more balanced media access. It was revealed, in the research about the Belgian newspapers and TV journalists' reaction to the Arab Spring protests in Syria, Egypt and Tunisia, that news coverage by the Belgian outlets adapted to new reality of "network journalism" (Van Leuven, Deprez, \& Raeymaeckers, 2014). The mass media shapes people's perception by choosing particular perspectives and ignoring others. The Arab Spring coverage by four US newspapers indicated variation in their presentations of the events. To cite, for instance, the New York Times adopted more thematic approach and seriously portrayed young Egyptians' protests against government for a change; the Washington Post provided more detailed stories by portraying a fierce battle between the protesters and the autocratic regime in Egypt; the USA Today relatively paid less attention to the uprising and gave more weight to the power of the US; and the International Herald Tribune paid close attention to the events with international perspective (Chung \& Cho, 2013).

\section{Method}

This study relies on a qualitative method of analysis, which has been found suitable for exploring events over a specific period of time (Silverman, 2012), for instance, the Arab Spring. Qualitative research targets societal issues and problem and hence serves humankind; it documents what events precede certain consequences; it illustrates multitude interpretations; and it is holistic in the sense that it offers rich understating than just snapshots (Tracy, 2013). The method is adopted to gain insight into underlying opinion (Teddlie \& Tashakkori, 2008) of the NI editorial writers. Analysis of themes, which aims to examine significant themes in a text or the process of deriving themes from data and illustrating these themes, is well-established part of qualitative research (Attride-Stirling, 2001).

\subsection{Data Collection}

The data for this study consist of editorials published in The News International (NI), which was founded in 1991 in Pakistan. It is one of the mainstream English language newspapers published in the country and claims a daily circulation of 140,000 . The newspaper is noticeable for its editorial coverage of various national, regional and international conflicts of different nature (Afzal, 2017; Shabir, Khan, Adnan, \& Safdar, 2014). This study has chosen editorials of the NI for analysing discursive strategies employed by its editorial writers in representing the Arab Spring. In the initial process of data collection, it was noticed that the newspaper published 40 opinion pieces (editorials) between the January 2011 and December 2012 time-period when media circulation of the uprising was on the rise. However, later, through further scrutiny of the collected data, editorial content was read and re-read for the purpose of analysis. Finally, with the assistance of certain keywords (e.g., Tunisia, Ben Ali, Yemen, Ali Abdullah Saleh, Libya, Qaddafi, Egypt, Mubarak, Syria Bashar al-Assad, Arab Spring, uprisings, revolutions, unrest, protests, protesters) all non-relevant editorials were discarded and the scope of sampling was narrowed down to 24 editorials as information-rich cases. 


\subsection{Data Analysis}

During the process of data analysis, editorials were read and re-read for discursive strategy of using themes to portray the uprising. These themes were inductively coded without any pre-determined classification. The selected themes represent the editorial writers' perspectives considered significant to the making of the Arab Spring discourse. Analysis of such themes refers to analysing, identifying, reporting different patterns within data sets and organising them into themes. The chosen editorials were analysed through coding method (Lindlof \& Taylor, 2002) based on the theoretical strands of discourse analysis. Codes used for themes represent relevant feature or content of data which interest analysts (Braun \& Clarke, 2006). In this article, each code exemplifies a theme under which relevant data chunks are noted. Furthermore, extracted themes representing the Arab Spring were categorised and analysed with selected examples, verbatim, from editorial excerpts. These editorials were coded in NVivo.

\section{Results and Discussion}

\subsection{The NI Representation of the Arab Spring}

The analysis of the editorial content of the NI has identified several 'pro-Arab Spring' themes which mainly depicted the actors (protesters vs. authorities) and their actions during the conflict. These key recurring themes included protests, horror, political instability, democracy and future developments as indicated in Table 1 whereas Figure 1 displays an overview of items (editorials) coded for analysis.

Table 1. Thematic construction of Arab Spring

\begin{tabular}{|c|c|c|c|c|c|c|}
\hline Editorial & $\begin{array}{c}\text { Countries of Arab } \\
\text { Spring }\end{array}$ & Protests & Horrors & $\begin{array}{l}\text { Political } \\
\text { instability }\end{array}$ & Democracy & $\begin{array}{c}\text { Future } \\
\text { developments }\end{array}$ \\
\hline 1. & Egypt & - & - & $\sqrt{ }$ & $\sqrt{ }$ & - \\
\hline 2. & General & $\sqrt{ }$ & - & $\sqrt{ }$ & - & - \\
\hline 3. & Egypt & $\sqrt{ }$ & & $\sqrt{ }$ & $\sqrt{ }$ & - \\
\hline 4. & Egypt & - & $\sqrt{ }$ & $\sqrt{ }$ & $\sqrt{ }$ & - \\
\hline 5. & Libya & $\sqrt{ }$ & - & $\sqrt{ }$ & - & - \\
\hline 6. & Libya & $\sqrt{ }$ & - & - & - & $\sqrt{ }$ \\
\hline 7. & General & & - & - & - & - \\
\hline 8. & Syria & $\sqrt{ }$ & - & - & - & - \\
\hline 9. & Libya & $\sqrt{ }$ & - & - & - & $\sqrt{ }$ \\
\hline 10. & Libya & - & - & - & $\sqrt{ }$ & $\sqrt{ }$ \\
\hline 11. & Egypt & $\sqrt{ }$ & - & $\sqrt{ }$ & $\sqrt{ }$ & - \\
\hline 12. & Syria & - & - & - & - & - \\
\hline 13. & Tunisia & - & - & - & $\sqrt{ }$ & - \\
\hline 14. & Egypt & - & - & - & $\sqrt{ }$ & - \\
\hline 15. & Syria & - & - & - & $\sqrt{ }$ & - \\
\hline 16. & Syria & $\sqrt{ }$ & $\sqrt{ }$ & $\sqrt{ }$ & - & - \\
\hline 17. & Syria & - & $\sqrt{ }$ & - & - & - \\
\hline 18. & Egypt & $\sqrt{ }$ & - & - & $\sqrt{ }$ & $\sqrt{ }$ \\
\hline 19. & Syria & - & $\sqrt{ }$ & - & - & - \\
\hline 20. & Syria & - & $\sqrt{ }$ & $\sqrt{ }$ & - & - \\
\hline 21. & Egypt & - & - & $\sqrt{ }$ & $\sqrt{ }$ & - \\
\hline 22. & Syria & - & - & - & $\sqrt{ }$ & - \\
\hline 23. & Syria & - & - & $\sqrt{ }$ & $\sqrt{ }$ & $\sqrt{ }$ \\
\hline 24. & Egypt & - & - & $\sqrt{ }$ & - & $\sqrt{ }$ \\
\hline
\end{tabular}




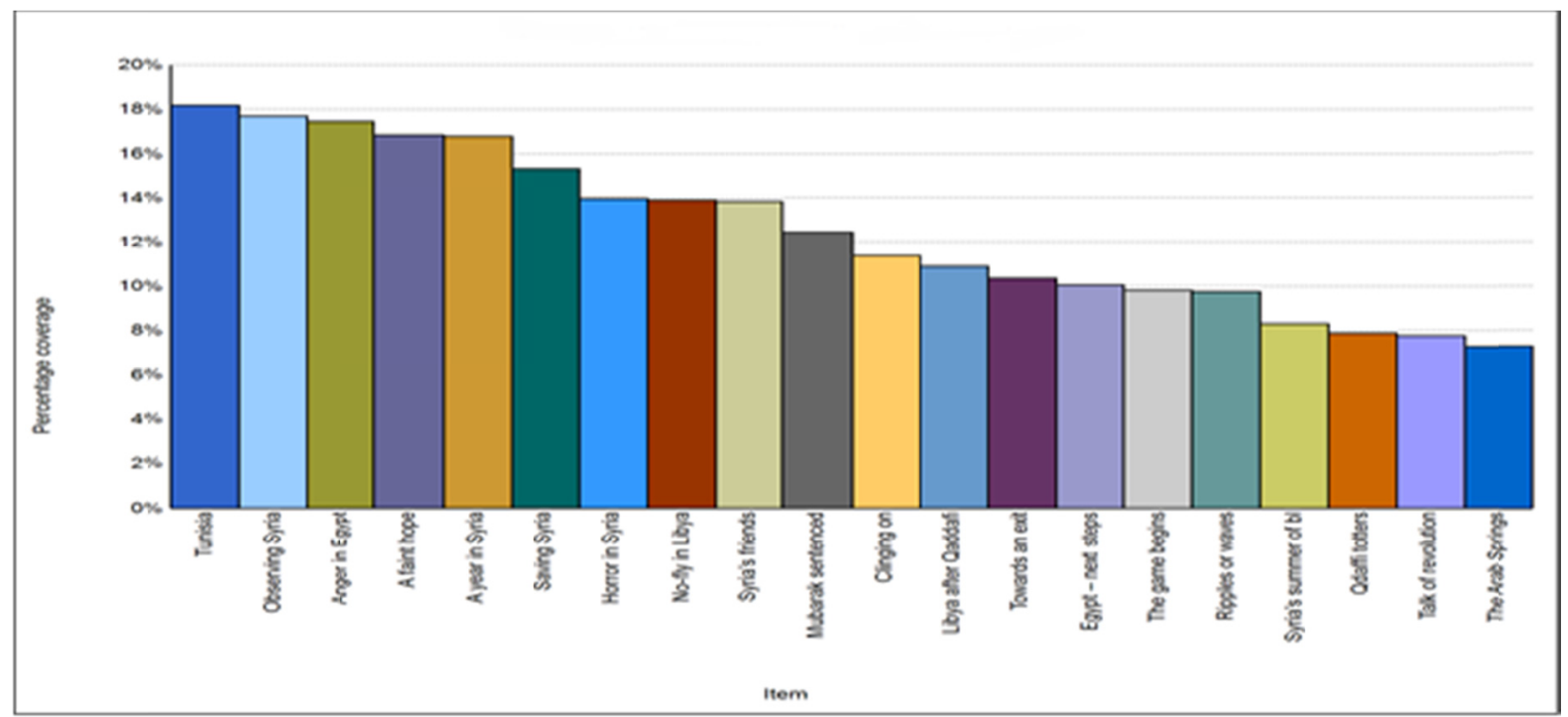

Figure 1. An overview of NI editorials content coded in NVivo

The media played a serious role in portraying the 2011 Arab Spring where diverse media channels including the newspapers were considered a dynamic force for stimulating anti-regime demonstrations. The media perspective of the Pakistani newspaper made several evaluative judgements which supported 'change' aspired through the Arab Spring. The editorials employed a discursive strategy of representing the conflict through themes which implied that the protesters in the uprising countries justly demanded removal of decade-old regimes. The study findings put forward that masses in these affected countries faced despotic laws and they were denied freedom and democracy which prompted them to take to streets. The NI portrayals of the Arab Spring in Libya and Syria particularly demonstrate that atrocious tactics were adopted to kill the protesting citizens and hinder their movements to destabilise authoritative rules. The opinion discourse in the mainstream news media has the potential to construct a kind of humanitarian communities (Greenberg, 2000). The NI's strategies of portraying events directs readers to concur with the paper's opinion of seeing the Arab Spring an 'initiative for change' launched by the media reporting the suppressed public in Tunisia, Yemen, Egypt, Libya and Syria. The study of such a media discourse becomes more meaningful when the intentions are to examine the way power is deployed through the linguistic practices or a specific genre of discourse, for instance editorials, or by the individuals (editors) who influence the events or have access to public domains (Reisigl \& Wodak, 2009). The analysis of the NI editorials unveiled the following Arab Spring themes.

\subsubsection{Protests: Self-generated Sense of Anger}

The editorial choices, for instance, self-generated sense of anger, revolution began and uprising denotes the theme 'protests'. This recurring theme occurred in seven editorials and fifteen comments. It reflected that the Arab Spring authorities (autocratic regimes) had to surrender powers, they had held for decades, due to protests which erupted in Tunisia and contagiously made a forcible entrance into other countries. Under the theme 'protest', the NI represented that protests which were prompted by self-generated anger translated into action across social, political and religious groups in the uprising countries. The paper portrayed the protests in Tunisia through the lexical choice street action which became a source of inspiration for events in Egypt-a positive representation of the paper to possibly favour pro-change development in the country. The newspaper also gave the credit to protesting Egyptians who were able to draw a list of 25 potential candidates for transitional government in the country. The editorial statement implies that Egyptians were never given a chance before the Arab Spring to vote democratically for candidates of their choice. Such an 'opinion discourse' adopts an integral role in forming the public opinion and assumes more critical role when political and social consensus are questioned. For news coverage to be ideological, establishing a reliable form of discourse is vital (Greenberg, 2000).

The NI constantly highlighted the place for holding protests through the comments a fourth day of mass protests in Tahrir Square, Tahrir Square quickly filled with protesters, the site of protests which demanded death penalty for the Egyptian authorities and consequently brought down the regime in a favour of 'change'. The action of 
arranging protests was described as people eventually threw off the shackles. Again, through this editorial opinion an impression is created that the Egyptian authorities suppressed their people and forced them to launch protests. The spread of the Arab Spring against the dictatorial regime in Libya was mainly linked with raging protests which were even supported by military. The NI declared that that protests in Libya grew rapidly, conflict as daily rather than weekly. Against the authoritative regime in Libya, the paper portrayed that Libya's diplomatic missions abroad also supported the protests, ambassadors resigning. The editorial declarations insinuate that the defiant Libyan authorities started losing their support both at home and abroad and hence it was time for 'change' in the country - a demand which was intensified through protests. Such media portrayals establish how the editorials advance newspapers' opinion where the editorial writers invoke their freedom to endorse certain practices and disdain others (Afzal, 2017).

\subsubsection{Horror: The Summer of Blood}

The verbatim comment the summer of blood reveals the manner in which the NI editorial writers frequently portrayed scenes of 'horror' which involved harsh treatments, killings and mass arrests faced by the Arab Spring protesters and launched by the autocratic governments. This theme occurred in fourteen editorials and twenty-three comments. Newspaper themes provide glimpse how the media cover events especially the themes which characterise the media representations of massacres (Petrella, 2014). For instance, related to the uprising in Egypt, it was reported that mass arrests were made and violence was committed against the protesters by the authorities who were found guilty of complicity in the killing. The paper further employed lexical choices such as brutal, ruthless security, police apparatus and principal architect to convey the message that the protesters were not given the liberty to demand change through the Arab Spring and instead they were forced to face inhumane treatments. It was also reported that the protesters in Egypt had to face live ammunition fired by the regime forces. Similarly, several editorial comments like 10,0000, 8,000, 500 and 300 protesters declared deaths faced by the protesters. Such editorial portrayals negatively portrayed the role of the Arab Spring authorities and suggest that decade-old regimes absolutely defied and resisted the 'wave' of change. The NI further asserted that the Libyan regime ordered to bomb or strafe civilians. Likewise, the editorial remarks about the Arab Spring in Syria, Bashar al-Assad is no more likely to listen to his people, indicated that the paper negatively evaluated anti-Arab Spring attitude of the Syrian rulers.

Hence, the media is not neutral as it may be claimed since newspaper contribute to conflicts either through positive or negative reproductions as long as they play a role in establishing attitude of certain elements in a society and propagating specific interests and goals (Omondi, 2016). The NI portrayals further depicted scenes of horror by reporting that Syrian city of Hama was attacked by forces loyal to the regime for three days - another indication how the authorities were committed to exterminate whatsoever related to the Arab Spring through brutal crackdowns. The metaphorical depiction summer of blood exemplified nothing but just massacres of Syrians by regime forces. The killings in Syria were reported so severe that the regime even banned journalists, observers and human rights groups to witness the sites of bloodiest attacks by troops, mass killings against civilians. Through some more lexical selections such as appalling massacre, dismembered bodies, wounds in the forehead, the NI blatantly criticised the Syrian regime for opposing the 'pro-change' protesters. On another occasion, the paper reported that in successive episodes of ever-escalating violence pro-Assad militia slew 200 villagers in Tremesh. Some other horrifying editorial judgements like bloody repression, slaughter its own people, bloodstained day, a continuum of violence and savagery represented the conditions in which the Arab Spring protesters had to pass through in Syria. Such shocking scenarios depicted by the editorial writers made the audience recognise the protesters' sufferings and sympathise with their demands.

\subsubsection{Political Instabilities: One-Party Dictatorships}

This theme was analysed in twelve editorials and sixteen comments. Under this theme, the writers portrayed several types of 'political instabilities' before and during the Arab Spring through the lexical choices, for instance, a shift in political polarities, old regimes, dynasties and so on. Such engagements of themes in news articles promote understanding of how themes are used for the purpose of legitimation and de- legitimation (Mikkola, 2017). The editorial judgement regaining control of their cultural, social and political identities suggested that the newspaper indirectly endorsed 'change' through the Arab Spring and rejected old authoritarian regimes. Another comment there has effectively been no power other than Gaddafi's government highlighted dictatorial power held by the Libyan leader and at the same time validated pro-Arab Spring sentiments and implicitly justified protestors' action of revolts who tolerated autocracy for years. The evaluative ruling turmoil in both states, Libya and Egypt, again highlighted political instability which prompted rebellion. The NI declared that people in Egypt were forbidden by law to stand in group exceeding more than five people. Such editorial assertions again reminds readers of a non-democratic rule in the country where people eventually 
break shackles of suppression. Further, through the theme 'political instability', it was pointed out that in a civil war in Libya the Arab Spring protesters entered in a stalemate with Qaddafi.

Likewise, due to instabilities the transition of power in Yemen during the uprising was also declared as increasingly doubtful which presumed a failure of 'change' to a democratic state. The situation in Libya was further portrayed through the comment that high political tensions in the country raised doubts over stability. Discourse produced by scholars such as from a reliable media source makes readers accept opinions, knowledge and beliefs. They see such discourse as trustworthy, authoritative and credible (van Dijk, 2008). Another lexical choice of the NI editorial writers, a kind of limbo, conveyed political uncertainty when civilian government in Egypt started resigning - the editorial predicted doubts about a stable government in the country. The dismissal of old Tunisian ruler through the Arab Spring protests was also represented as the departure of one-party dictatorship. The NI kept frequently reminded audiences that the Arab Spring was caused by dictatorial tactics such as in Syria, where people tried to replicate what happed in Tunisia, Yemen, Egypt and Libya. As per the editorial blames, the Assad regime exploited weak opposition and benefited from their disunity. The paper also criticised opposition sects and factions for remaining instable due to their vested interests and failing to provide a strong front against Assad. Their political instability was further depicted through critical comments like fragmentary opposition, inability to come together under a single platform because they failed to dislodge Assad's regime and present a united front against the Syrian regime.

\subsubsection{Democracy: A New Political Future Awaited}

Under the banner of the theme 'democracy', largely, the NI propagated the Arab Spring revolts as a movement launched by the protesters to restore democratic values accompanied by some hardships. This theme was analysed in eleven editorials and nineteen comments. For instance, the paper acknowledged that Egypt would address a new political future and protesters drew up a list of 25 potential candidates for a transitional government. Similarly, the lexical choice committed to democratic process implied that the newspaper positively portrayed the post-Arab Spring government in Egypt. As acknowledged, writers' variety of words expresses what they deliberate relevant to a topic. These words, characterising persons, groups or events that shape a conflict are selected from range of options to legitimate an ideology propagated through discourse themes (Wenden, 2005). The situation in Tunisia was also positively described as a democracy in progress. Another editorial conviction, the end of tyranny and dictatorship, accepted the exit of old regimes in the uprising countries. Hence, once again the mainstream newspaper backed protesters' triumph. Hence, it has been proven that the media representation of conflicts is hardly neutral (van Dijk, 2000). It was also declared that a national body, National Transitional Council, was formed in Libya to arrange a new democratic system. Some other editorial remarks such as elections are due, national parliament, change against apparatus of power, democratic future also hinted at formation of democratic governments in the wake of the uprising. The situation in Tunisia was also represented promising thorough the lexical choices democracy was quick to take roots and many political parties wanted to be part of new governance consequent upon the Arab Spring.

The newspaper praised Tunisians' elections through positive judgments such as credible election and negatively evaluated the old government as Ancien Régime. For the Egyptian case, it was declared that due to Arab Spring the country first time in half a century exercised democratic rights. On another occasion, the paper expressed its satisfaction over democratic changes through the evaluative judgement that elections in Tunisia and Egypt passed international scrutiny. In favour of democracy in the aftermath of the Arab Spring, the NI even disliked the Egyptian army holding powers through the comment mockery of democratic processes. Raising its concern over growing unrest in Syria, the paper strongly urged for a democratic change through diplomatic and economic channels. The lexical choice post-colonial shakeout of regimes also implied that the paper approved demands of the Arab Spring protesters for democratic governments. Similarly, the comment party politics were absent also signalled a democratic change in Egypt when the country was passing through painful transition. The newspaper also recommended that a pluralist government should be promoted rather than any puppet regime. Such editorial selection of lexical choices further backed democracy. It is argued that while writing on topical issues newspaper discourse reflect certain pattern of language to implant their ideologies. Journalists controlling newspaper articles also manipulate genres (e.g., editorials) to negotiate ideologies and control reader's mind as they wish. Due to such journalistic practices, discourse may become more ideology driven than objective driven (Fornkwa, 2015).

\subsubsection{Future Developments: Rehabilitation and Rebuilding}

The theme 'future developments' occurred in eleven editorials and fourteen comments. It represents that the newspaper, despite backing up the Arab Spring movement and democratic aspirations it carried, also shared its 
concern about future developments and rehabilitations in the conflict-torn countries. The analysis of news articles discloses the way newspaper play an instrumental role in addressing issues in society through their discursive constructions and their language has indications beyond conveying information in a simple way (Ali, Christopher, \& Nordin, 2016). The NI predicted that due to the crises in Libya soaring oil prices would seriously affect global economy. The NI also asserted that Libyans needed help and support in the wake of the Arab Spring like Egyptians and Tunisians to assure smooth transitions from one government to another. It also suggested that NATO had the expertise to reconstruct and repair Libya as it did in Kosovo and Bosnia. Some lexical choices such as rehabilitation project era, wider international support, battle for reconstruction and equitable development suggested that the newspaper seriously treated the post-uprising developments in these countries. The NI also asserted that Libyans needed inward investment to ensure prosperous governance in the country. The newspaper further evaluated that the Arab Spring protesters failed to put together a united coalition which could provide a strong basis for a post-Assad government in future - an early predication which could not come true and the Syrian regime has survived since the breakout of the uprising. The NI also insisted that a political recognition of an entity was must to form a credible government in Syria. However, the paper negatively represented the future of Syria as indicated through evaluative opinion such as endless war, inconclusive results, division of Syria and so on. Like Libya and Syria, the NI also propagated its concerns that rebuilding Egypt, a country of civilisations, will never going to be an easy task. Such NI representations may concur with the notion that media discourse plays both a positive role in stopping conflicts and propagating peace and negative a role in escalating conflicts (Omondi, 2016).

\section{Conclusion}

This article proves that discourse analysis plays an instrumental role in making sense of the media discourse. It explores media representation (NI) in times of the Arab Spring conflict and confirms the presence of several recurring discourse themes. It demonstrates the way editorial writers employed discursive themes to propagandise 'change' in the countries of the Arab Spring by endorsing the protesters' demands through positive beliefs and disapproving the decade-old authoritative through negative beliefs. The themes highlighted in this study demonstrate enough potential to instil pro-Arab Spring sentiments in masses and develop pro-change perceptions in the public while eying events from outside the boundaries of Arab nations. This study communicates how the senior media workers (e.g., editorial writers) rely on specific discursive strategies to destabilize/undermine some factions of conflicts or the way the media discourse contributes to implicitly ratifying 'popular segments' in a two-sided conflict, for instance, the protesters in the case of Arab Spring. Such media characterisation of events and actors, for instance through the NI discourse, serves to be insightful in realising the way the media narrations broaden our perspective on global issues - the Arab Spring inclusive of it. Thus, the media portrayals contribute to impact on our assessment of conflicts as readers and assign values to our justification of certain viewpoints we construct under the influence of such portrayals. This article advocates that newspaper editorials as a dominant form of 'opinion discourse', which reflect 'institutional powers' and force readers to reconsider their decision on sensitive issues, should not go unnoticed with regard to representation of conflicts of international concern.

Nevertheless, this study has some limitations. First, bound by timeframe, it relies on the newspaper editorials which mostly circulated episodes related to the just break-out of the Arab Spring and, hence, does not fully cover the post-Arab Spring scenarios. For such reasons, its findings related to dominant themes are limited for generalising the whole of the conflict. Secondly, this study focuses on just one newspaper belonging to a non-Arab country and, therefore, many not suffice to deliver a comprehensive view of the Arab Spring conflict. In consideration of these limitations, this study recommends that future studies should expand the time frame to examine more Arab Spring developments. In addition, to enrich the exiting literature, future investigators should diversify the sample by selecting editorials from different newspapers in different countries.

\section{References}
Abusharif,
I. $\quad \mathrm{N}$.
(2014).
Parsing
Arab
Spring. https://www.qatar.northwestern.edu/docs/2014-Parsing-Arab-Spring.pdf

Abushouk, A. I. (2014). Time and Newsweek's coverage of the Arab uprisings in 2011: A content analysis survey. Asian Review of World Histories, 2(1), 81-104. https://doi.org/10.12773/arwh.2014.2.1.081

Acemoglu, D., Hassan, T. A., \& Tahoun, A. (2014, November). The power of the street: Evidence from Egypt's Arab spring (No. 20665). NBER Working Paper. 
Aday, S., Farrell, H., Lynch, M., Sides, J., \& Freelon, D. (2012). New media and conflict after the Arab spring (Research Report No. 80). Retrieved from United States Institute of Peace website: http://www-dev.usip.org/sites/ default/files/PW80.pdf

Afzal, N. (2017). The media portrayal of Arab Spring in newspaper editorials: The case of Pakistani the News International and Saudi Arabian Arab News (unpublished doctoral dissertation). Universiti Utara Malaysia, Sintok, Malaysia.

Ali, M. K., Christopher, A. A., \& Nordin, M. Z. F. B. (2016). Linguistic legitimation of political events in newspaper discourse. Advances in Language and Literary Studies, 7(4), 76-83.

Alian, N. H. M. (2016). The representation of the arab spring narrative in English and Arabic news media (Doctoral dissertation, University of Leeds, UK). Retrieved from http://etheses.whiterose.ac.uk/17742/

Attride-Stirling, J. (2001). Thematic networks: An analytic tool for qualitative research. Qualitative research, 1(3), 385-405. https://doi.org/10.1177/146879410100100307

Baum, M. A., \& Zhukov, Y. M. (2015). Filtering revolution: Reporting bias in international newspaper coverage of the Libyan civil war. Journal of Peace Research, 52(3), 384-400. https://doi.org/10.1177/0022343314554791

Blaydes, L., \& Lo, J. (2012). One man, one vote, one time? A model of democratization in the Middle East. Journal of Theoretical Politics, 24(1), 110-146. https://doi.org/10.1177/0951629811423121

Braun, V., \& Clarke, V. (2006). Using thematic analysis in psychology. Qualitative research in psychology, 3(2), 77-101. https://doi.org/10.1191/1478088706qp063oa

Bruce, M. D. (2014). Framing Arab Spring conflict: A visual analysis of coverage on five transnational Arab news channels. Journal of Middle East Media, 10(1), 1-26. https://doi.org/10.12816/0023470

Campbell, H., \& Hawk, D. (2012). Al Jazeera's framing of social media during the Arab spring. CyberOrient, $6(1)$.

Canagarajah, A. S. (1999). Resisting linguistic imperialism in English teaching. New York, NY: Oxford University Press.

Cassol, H., Pétré, B., Degrange, S., Martial, C., Charland-Verville, V., \& Lallier, F. et al. (2018) Qualitative thematic analysis of the phenomenology of near-death experiences. PLOS ONE, 13(2), e0193001. https://doi.org/10.1371/journal.pone.0193001

Chung, C. J., \& Cho, S. H. (2013). News coverage analysis of SNSs and the Arab Spring: Using mixed methods. Global Media Journal, 12(23).

Ciechanowski, K. (2012). Conflicting discourses: Functional linguistic and discourse analyses of Pocahontas texts in bilingual third-grade social studies. Journal of Literacy Research, 44(3), 300-338. https://doi.org/10.1177/1086296X12450699

De Wet, C. (2001). A media discourse analysis of racism in South African schools. International Education Journal, 2(5), 98-112.

Dube, J. (2013). International new media coverage of the "Arab springs": Actors, technology and political impacts (Master's thesis, Clark Atlanta University, Atlanta, Georgia). Retrieved from http://digitalcommons.auctr.edu/ cgi/viewcontent.cgi?article= 2625\&context=dissertations

Fairclough, N. (1995). Media discourse. London, England: Edward Arnold.

Fairclough, N. (2013). Language and power (3rd ed.). London, England: Routledge.

Fairclough, N., \& Wodak, R. (1997). Critical discourse analysis. In T. A. van Dijk (Ed.), Discourse as social interaction (pp. 258-284). London, England: SAGE Publications.

Fornkwa, M. J. (2015). A Critical Discourse Analysis of newspaper articles on the 2015 state budget of Cameroon in the national press [PowerPoint slides]. Retrieved from https://www.tu-chemnitz.de/phil/ english/sections/ling/download/CameroonAvH15/16.\%20Marcel\%20Jaff.pdf

Fowler, R. (2013). Language in news: Discourse and ideology in the press. London, England: Routledge. https://doi.org/10.4324/9781315002057 
Fulton, H. (2005a). Introduction: The power of narrative. In H. Fulton, R. Huisman, J. Murphet, \& A. Dunn (Eds.), Narrative and media (pp. 1-8). Cambridge, England: Cambridge University Press. https://doi.org/10.1017/CBO9780511811760.001

Fulton, H. (2005b). Print news as narrative. In H. Fulton, R. Huisman, J. Murphet, \& A. Dunn (Eds.), Narrative and media (pp. 218-244). Cambridge, England: Cambridge University Press. https://doi.org/10.1017/CBO9780511811760.016

Gee, J. P. (2014). An introduction to discourse analysis: Theory and method (4th ed.). New York, NY: Routledge.

Gnanaseelan, J. (2012). A discourse analysis of ethnic conflict and peace in the editorials of English newspapers a case study of Sri Lanka. Sri Lanka Journal of Advanced Social Studies, 1(2), 46-68. https://doi.org/10.4038/sljass.v1i2.4856

Gnanaseelan, J. (2015). The metaphors on international intervention: A discourse analysis of the Sri Lankan English newspaper editorials. International Journal of Applied Linguistics and English Literature, 4(4), 2135 .

Greenberg, J. (2000). Opinion discourse and Canadian newspapers: the case of the Chinese boat people. Canadian Journal of Communication, 25(4). https://doi.org/10.22230/cjc.2000v25n4a1178

Hashemi, N. (2013). The Arab spring two years on: Reflections on dignity, democracy, and devotion. Ethics \& International Affairs, 27(02), 207-221. https://doi.org/10.1017/S0892679413000099

Hussain, S., \& Munawar, A. (2017). Analysis of Pakistan print media narrative on the war on terror. International Journal of Crisis Communication, 1(1), 38-47.

Johnson, S., \& Milani, T. M. (Eds.). (2010). Language ideology and media discourse: Texts, practices, politics. New York, NY: Continuum International Publishing Group.

Junne, G. (2013). The role of media in conflict transformation. Retrieved from http://www.irenees.net/bdf_fiche-analyse-1002_en.html

Karkouti, M. (2016, January 2). Arab Spring roots run deep. Gulf News. Retrieved from http://gulfnews.com/opinion/thinkers/arab-spring-roots-run-deep-1.1647 267

Kashefi, M. (2013). The Arab spring and its theoretical significance: Samuel Huntington's theory, the clash of civilizations, revisited. Societies Without Borders, 8(2), 178-204.

Khosrokhavar, F. (2016). New Arab revolutions that shook the world (2nd ed.). London, England: Routledge. https://doi.org/10.4324/9781315633275

Krotofil, J., \& Motak, D. (2018). A critical discourse analysis of the media coverage of the migration crisis in Poland. Scripta Instituti Donneriani Aboensis, 28, 92-115. https://doi.org/10.30674/scripta.70069

Laub, K. (2011, September 8). Libyan estimate: At least 30,000 died in the war. The Guardian. Retrieved from http://www.guardian.co.uk/world/feedarticle/983 5879

Ledwell, C. (2014). Ideology no more: A discourse of othering in Canadian mainstream newspaper representations of the idle no more movement. Retrieved from http://www.lse.ac.uk/media-and-communications/assets/documents/research/msc-dissertations/2013/109-Le dwell.pdf

Lee, F. L. F., \& Lin, A. M. Y. (2006). Newspaper editorial discourse and the politics of self-censorship in Hong Kong. Discourse and Society, 17(3), 331-358. https://doi.org/10.1177/0957926506062371

Lindlof, T. R., \& Taylor, B. C. (2002). Qualitative communication research methods (3rd ed.). Thousand Oaks, CA: SAGE Publications.

Lindsey, R. A. (2013). What the Arab Spring tells us about the future of social media in revolutionary movements. $\quad$ Retrieved from http://citeseerx.ist.psu.edu/viewdoc/download?doi=10.1.1.373.1513\&rep=rep1\&type=pdf

Long, P. (2014). Media studies: Texts, production, context. London, England: Routledge. https://doi.org/10.4324/9781315833071

Mikkola, M. (2017). Discursive (de)-legitimation strategies in the media-a case study of Finnish co-operation negotiations during the economic downturn in 2008-2015 (Master's Thesis, Aalto University, Finland). Retrieved from https://aaltodoc.aalto.fi/handle/123456789/27810 
Moaddel, M. (2012). The Arab spring and Egyptian revolution makers: Predictors of participation (PSC Research Report No. 12-775). Retrieved from http://www. psc.isr.umich.edu/ pubs/pdf/rr12-775.pdf

Ng, S. H. (2008). A critical discourse analysis of representations of bilateral issues concerning Malaysia and Singapore in mainstream newspaper editorials (Doctoral dissertation, Universiti Putra Malaysia, Seri Kembangan, Malaysia). Retrieved from http://psasir.upm.edu.my/5646/

Omondi, C. A. (2016). Media Discourse and Ethnic Conflicts: A Critical Discourse Analysis of Online Newspaper Editorials in Kenya (Master's thesis, University of Helsinki, Finland). Retrieved from https://helda.helsinki.fi/bitstream/handle/10138/169667/Clarice\%20Omondi\%20M.A\%20thesis.pdf?sequen $\mathrm{ce}=2$

Paltridge, B. (2012). Discourse analysis: An introduction (2nd ed.). London, England: Bloomsbury.

Petrella, J. A. (2014). Black, white, and red all over: A thematic analysis of selected Canadian and American newspapers coverage of the 1968 Mexico City massacre (Master's Thesis, The University of Western Ontario, Canada). Retrieved from https://ir.lib.uwo.ca/etd/2215

Ramadan, W. (2014). Media coverage of the Arab Spring and the new Middle East (Special Report).

Rasul, A., \& Asim, M. M. (2014). How US newspapers framed the Arab Spring. Media Asia, 41(1), 86-100. https://doi.org/10.1080/01296612.2014.11690002

Reisigl, M., \& Wodak, R. (2009). The discourse-historical approach (DHA). In R. Wodak \& M. Meyer (Eds.), Methods of critical discourse analysis (2nd ed., pp. 87-121). London, England: SAGE Publications.

Salaita, S. (2012). Corporate American media coverage of Arab revolutions: The contradictory message of modernity. Interface, 4(1), 131-145.

Shabir, G., Khan, A. W., Adnan, M., \& Safdar, G. (2014). A comparative analysis of the editorials of The Nation and The News: The case study of Pak-India relations issues (2008-2010). Journal of Political Studies, 21(1), 41-59.

Shoemaker, P. J., \& Reese, S. D. (2013). Mediating the message in the 21st century: A media sociology perspective (3rd ed.). New York, NY: Routledge. https://doi.org/10.4324/9780203930434

Silverman, D. (2012) Doing qualitative research: A practical handbook (4th ed.). London, England: SAGE Publications.

Talbot, M. (2007). Media discourse: Representation and interaction. Edinburgh, Scotland: Edinburgh University Press.

Teddlie, C., \& Tashakkori, A. (Eds). (2008). Foundations of mixed methods research: Integrating quantitative and qualitative approaches in the social and behavioural sciences. Thousand Oaks, CA: SAGE Publications.

Törnberg, A., \& Törnberg, P. (2016). Muslims in social media discourse: Combining topic modeling and critical discourse analysis. Discourse, Context \& Media, 13, 132-142. https://doi.org/10.1016/j.dcm.2016.04.003

Tracy, S. J. (2013). Qualitative research methods. West Sussex, England: Wiley-Blackwell.

van Dijk, T. A. (1985). Introduction: The role of discourse analysis in society. In T. A. van Dijk (Ed.), Handbook of discourse analysis (Vol. 4, pp. 1-8). London, England: Academic Press.

van Dijk, T. A. (1991). The interdisciplinary study of news as discourse. In K. B. Jensen \& N.W. Jankowski (Eds.), A handbook of qualitative methodologies for mass communication research (pp. 108-120). New York, NY: Routledge.

van Dijk, T. A. (1992). Racism and argumentation: Race riot rhetoric in tabloid editorials. In F. H. van Eemeren et al. (Eds.), Argumentation illuminated (pp. 242-259). Dordrecht, The Netherlands: Foris.

van Dijk, T. A. (1995). Power and the news media. In D. Paletz (Ed.), Political communication and action (pp. 9-36). Cresskill, NJ: Hampton Press.

van Dijk, T. A. (1998a). Ideology: A multidisciplinary approach. London, England: SAGE Publications.

van Dijk, T. A. (1998b). Opinions and ideologies in the press. In A. Bell \& P. Garrett (Eds.), Approaches to media discourse (pp. 21-63). Oxford, England: Blackwell.

van Dijk, T. A. (2000). New(s) racism: A discourse analytical approach. In S. Cottle (Ed.), Ethnic minorities and the media (pp. 33-49). Milton Keynes, England: Open University Press. 
van Dijk, T. A. (2004). From text grammar to critical discourse analysis: From text grammar to critical discourse analysis: A brief academic autobiography. Retrieved from http://www.discourses.org/

van Dijk, T. A. (2008). Discourse and power. Hampshire, England: Palgrave Macmillan. https://doi.org/10.1007/978-1-137-07299-3

van Dijk, T. A. (2013). News as discourse. New York, NY: Routledge. https://doi.org/10.4324/9780203062784

van Dijk, T. A. (Ed.). (1997). Discourse as structure and process. London, England: SAGE Publications.

van Leuven, S., Deprez, A., \& Raeymaeckers, K. (2014). Networking or not working? A comparison of Arab Spring coverage in Belgian newspapers and TV news. Journalism Practice, 8(5), 552-562. https://doi.org/10.1080/17512786.2014.894325

Wenden, A. L. (2005). The politics of representation: A critical discourse analysis of an Aljazeera special report. International Journal of Peace Studies, 89-112.

Youssef, M., Arafa, H., \& Kumar, A. (2014). Mediating discourse of democratic uprising in Egypt: Militarized language and the "battles" of Abbasiyya and Maspero. International Journal of Communication, 8, 871889.

Zahid, Z. M. (2016). USA versus 'Them': Fomenting an Enemy for the Hegemonic Discourse. IPRI Journal, $16(2), 105-118$.

\section{Copyrights}

Copyright for this article is retained by the author, with first publication rights granted to the journal.

This is an open-access article distributed under the terms and conditions of the Creative Commons Attribution license (http://creativecommons.org/licenses/by/4.0/). 